the closed window cases refer chiefly to last generation. Thus these figures might also to a great extent be said to show that adenoids were rare a generation ago and very common at the present day. Whether there have been other changes which might account for the apparently great increase in the prevalence of adenoids is a point to be considered; but it certainly seems very desirable that an investigation should be made into the preportion of children affected with adenoids at the present day and a similar investigation into the proportion of those who suffered from the disease, say, 30 or 40 years ago. This latter could no doubt be arrived at from the history of the cases, the shape of the palate, and the arrangement of the teeth. The necessary information could at least be more satisfactorily got if such an investigation were made at once. It would be wasting a good opportunity to wait till skeletal evidence was our only data to go upon. I am, Sir, yours faithfully,

Wimpole-street, W., Feb. 22nd, $1908 . \quad$ J. SIM WALLACE.

\section{THE LOCKING OF MILK CHURNS.}

To the Editor of THE LaNceT.

SIR,-In reference to your annotation in your issue of Feb. 22nd on the above subject $I$ beg to inclose for your information a copy of the contract which every farmer who supplies milk to the Aylesbury Dairy Company is required to sign and from which you will see that every churn of milk has to be sealed, that for this purpose the company provide the necessary seals and sealing pliers, and that milk received in a churn not securely sealed is made into butter and paid for accordingly. This practice has been in operation for the past 20 years at least.-I am, Sir, yours faithfully,

J. A. HatTersLeY, Managing Director. Aylesbury Dairy Co., Limited,

St. Petersburgh-place, Bayswater, London, W. Feb. 22nd, 1908 .

* * The sixth clause of the contract signed between the Aylesbury Dairy Company and the contractors for cows' milk runs as follows :-

6. Every churn of milk to be sealed, and for this purpose the company to provide the necessary seals and sealing pliers, which are to be returned to them on the expiration of the contract, or at an earlier period if demanded by the company. Milk received in a churn which according to market price of butter.

This is a very proper clause and one which we should like to see enforced by all other agents in the distribution of milk, for there can be no denying that a great quantity of milk reaches London in unsealed cans. At the beginning of last year we published a short series of articles from a correspondent in which he detailed his personal observations upon the railway transport of milk. In the course of his articles his remark that he had seen cans containing milk upon various London platforms with their lids unfastened and partly open became monotonously frequent.--ED. L.

\section{DIPHTHERIA OF THE SKIN.}

\section{To the Editor of THE LANCET.}

SIR,-In reference to the two remarkable cases of diphtheria of the skin with vesicular or ecthymatous lesions recorded by Dr. Alan B. Slater (THF LANCET, Jan. 4th, p. 15) and by Dr. A. Eddowes (THE LANCET, Feb. 1st, p. 282) it is interesting to recall two similar cases reported by Labbé and Demarque (Impetigo and Ecthyma due to Bacillus of Diphtheria, Rev. Mens. des Mal. de l'Enfance, February, 1904, p. 49), and a case recorded by Schucht (Dermatitis due to true Diphtheria Bacillus, Case 4, "with the clinical picture of infantile ecthyma," Archiv f. Derm. u. Syph., Neisser's Festsohrift, 1907, p. 105).

I am, Sir, yours faithfully,

Weymouth-street, W., Feb. 18th, $1908 . \quad$ H. G. ADAMSON.

\section{THE SUPPLY OF PURE MILK HOSPITALS.}

To the Editor of THE LANOEr.

SIr, - I have been greatly interested in the report of the committee on the supply of milk to the London hospitals. Perhaps it will be best if $I$ say at once that $I$ am in active practice in Lincolnshire and also a partner in a fairly large farming business with a dairy of between 60 and 70 cows in the South of England. I can therefore look at this question both from the medical and agricultural point of view. I should like to point out that the conditions of the first clause as to the percentage of butter fat are at some times and in certain seasons quite impossible to carry out. I will also try to prove that even the attempt to carry out the conditions will render the milk a source of danger to a certain number of young children.

Some two or three years ago during the months of April, May, and half of June, we could not possibly obtain a yield of 3 per cent. from the cows on the farm mentioned above and we found that every other dairy farm in that district complained of the same thing. Some time before this I inspected the cows, buildings, sc., and was satisfied as to the health and condition of the cows, but to make doubly sure I suggested a visit from the medical officer of health of the large town where the milk is consumed. He reported the cows to be most healthy and everything carried out under the very best conditions. The grass land on which the cows feed is of good quality, in fact, far above average dairy land. The weather was very cold and sunless, so that the best grasses did not come until the third week in June. During this period, from April to June, the milk was tested daily with the result that during the whole time the fats were nearly always below 3 per cent. Many experts were appealed to for the cause and remedy, amongst others the Royal Agricultural Society ; they all advised an increase of albuminous foods. This, of course, had been done all the time, they having as much best cotton cake, oats, and beans as they would eat, these being the usual foods for the purpose. Singularly, the cows that were the greatest offenders had only been in milk about a month or six weeks. The same cows during the months of October and November of that year, and on the same land without any artificial food, yielded 6 per cent. of fats at every milking. So much for the agricultural side of the question; now for the medical. Nearly all farmers who regularly breed and rear calves are quite conversant with the fact that if they give a cow an excess of albuminous food whilst the calf is sucking almost certain death of the calf follows, and that quickly, from "skate" or violent diarrhce which has a most peculiarly offensive smell. I have received direct evidence of this from farmers in Devon, Sussex, Northants, and Lincolnshire. I have also most conclusive evidence that this milk will have the same effect on some infants. I will give two cases from many that have come under my personal observation during the past year or two. Case 1: A lady with her infant, in perfect health, came to stay on the above farm during the time the cows were giving less than 3 per cent. of fats. My partner, the farmer, said, "If the baby takes this milk she will have diarrhoea in 24 hours." The infant had the milk and it was followed by the diarrhœa in less than 48 hours, the motion having the same peculiar smell as the calf's has. Case 2: I casually asked a farmer what his 15-months old boy had been fed on; he replied, "The milk from a thoroughly healthy young cow." Then he volunteered the fact that when the child was six months old he gave the cow some cotton cake, bahy at once getting diarrhoea; he stopped cotton cake and the diarrhoea ceased.

The two cases led me to investigate many attacks of diarrhoea in infants and I am convinced the above is frequently the cause. It can be diagnosed by the peculiar odour and cured by stopping the milk. I am anxious to find what it is in the milk that causes this trouble and should be glad to hear from any of your readers if they have had a similar experience as myself. It seems to me there must be a ptomaine in the milk, which is almost certain death to the calf and only acts spasmodically on the infant.

One final remark on the committee's report for the hospitals. Why not insist on the cows being milked by a milking machine, the milk entering a hermetically sealed vessel direct from the cows and so avoid dirty hands, \&c.? We have adopted this course and so far we are more than pleased with the result from both the farming and sanitary point of view.

Feb. 25th, 1908. I am, Sir, yours faithfully, M.R.C.S., L.R.C.P.

ERratuM. - In Dr. Harry Campbell's letter published in the last issue of THE LANCET the word "respiration" occurring in the ninth line should be "expiration." 